\title{
Absence of Hepatic Impairment in Long-term Oral-contraceptive Users
}

\author{
G. I. M. SWYER,* M.A., D.M., M.D., D.PHIL., F.R.C.P. ; VALERIE LITTLE, $†$ M.B., B.S., B.SC.
}

Brit. med. F., 1965, 1, 1412-1414

Although it has long been known that certain steroids, particularly those with an alkylated group at $\mathrm{C} 17$, may occasionally prove hepatotoxic, no serious suspicion that currently used oral contraceptives might have such an action was generally entertained until Eisalo et al. (1964) presented evidence of hepatic dysfunction in seven post-menopausal women treated for 28 days with Lyndiol ( $17 \alpha$-ethynyloestrenol $5 \mathrm{mg}$. and mestranol $0.15 \mathrm{mg}$.), at double the usual oral contraceptive dose in five of them. This evidence consisted of pathological increases in the serum transaminase levels in all cases and of high bromsulphthalein retention in the three cases tested; the total bilirubin was elevated in one case and the alkaline phosphatase in one case on the day following the treatment. The progestogen alone was found to be without hepatotoxic effect in two patients given it, and one out of three patients given mestranol alone showed a rise in serum transaminase.

This report has been followed by several others dealing with oral contraceptives and liver damage. Thus Tyler (1964a) encountered abnormal bromsulphthalein retention and transaminase figures in "small percentages" of women using various oral contraceptives, but found "comparable" percentages among normal pregnant women. Palva and Mustala (1964), reporting like Eisalo et al. from Helsinki, treated five post-menopausal women for 28 days with Anovlar (norethisterone acetate $4 \mathrm{mg}$. and ethinyloestradiol $0.05 \mathrm{mg}$.) and found raised transaminase and B.S.P. retention in all cases, high serum bilirubin in two, and slightly elevated alkaline phosphatase in three. Linthorst (1964), on the other hand, could find no evidence for hepatic dysfunction in 52 women who had received long-term treatment with $17 \alpha$-ethynyloestrenol (Orgametril), Lyndiol, or Lyndiol 2.5 (half the dose of Lyndiol). Rice-Wray (1964) states that she found no evidence for liver damage, as judged by serum glutamic pyruvic transaminase (S.G.P.T.) tests, in 56 women who had used Lyndiol in from 3 to more than 12 cycles. Adlercreutz and Ikonen (1964) have seen three cases of jaundice "due to contraceptive pills" in Helsinki, while a case of severe intrahepatic cholestasis during treatment with Volidan (megestrol acetate $4 \mathrm{mg}$. and ethinyloestradiol $0.05 \mathrm{mg}$.) was reported by Sotaniemi et al. (1964)-also from Finland. Further comments have been made by Tyler (1964b) and by Swaab (1964), the latter having encountered no cases of hepatic damage among his considerable group of women using oral contraceptives.

The uncertainties engendered by these recent communications have prompted us to carry out a series of liver-function tests on a small number of women who have been using various oral contraceptives continuously for periods ranging from 41 to 73 cycles-that is, three to six years. With the exception of abnormalities in certain of the empirical liver-function tests, the results in all 12 cases have been reassuringly normal.

\section{Material and Methods}

The 12 patients, whose ages range from 29 to 42 years, are all volunteers who have been using oral contraceptives for not

\footnotetext{
* Consultant Endocrinologist, Department of Obstetrics and Gynaecology, University College Hospital, London.

+ Clinical Research Assistant, Department of Obstetrics and Gynaecology, University College Hospital, London.
}

Table I.-Clinical Details of Patients

\begin{tabular}{|c|c|c|c|c|c|}
\hline Case & Age & Parity & Drugs & \multicolumn{2}{|c|}{$\begin{array}{l}\text { No. of } \\
\text { Cycles }\end{array}$} \\
\hline 1 & 29 & $\begin{array}{c}+\frac{1}{2} \\
\text { terminations }\end{array}$ & $\begin{array}{l}\text { Anovlar } \\
\text { Lyndiol }\end{array}$ & $\left.\begin{array}{r}5 \\
36\end{array}\right\} 4$ & 41 \\
\hline 2 & 41 & 7 & $\begin{array}{l}\text { Meg. ac. } 2 \mathrm{mg} .+ \text { mestr. } 0.1 \mathrm{mg} . \\
\text { Meg. ac. } 3 \mathrm{mg} \text { + mestr. } 0.1 \mathrm{mg} . \\
\text { Meg. ac. } 5 \mathrm{mg} \text { + mestr. } 0.1 \mathrm{mg} . \\
\text { Meg. ac. } 2 \mathrm{mg} \text { + E.0. } 0.05 \mathrm{mg} \text {. } \\
\text { Lyndiol } \\
\text { Anovlar } \\
\text { B.D.H. Sequential } \\
\text { Volidan } \\
\text { Ethynodiol diac. } 0.5 \mathrm{mg} .+ \text { mestr. } 0.1 \mathrm{mg} .\end{array}$ & $\left.\begin{array}{r}3 \\
3 \\
3 \\
3 \\
3 \\
15 \\
3 \\
6 \\
6\end{array}\right\} 4$ & 45 \\
\hline 3 & 39 & 4 & $\begin{array}{l}\text { Meg. ac. } 3 \mathrm{mg} .+ \text { mestr. } 0.1 \mathrm{mg} \text {. } \\
\text { Lyndiol } \\
\text { Anovlar } \\
\text { Ethynodiol diac. } 3 \text { mg. }+ \text { mestr. } 0.1 \mathrm{mg} . \\
\text { WY } 37071 \mathrm{mg} .+ \text { E.O. } 0.05 \mathrm{mg} \text {. } \\
\text { Lyndiol } 2.5\end{array}$ & $\left.\begin{array}{r}6 \\
18 \\
3 \\
3 \\
3 \\
7\end{array}\right\} 4$ & 43 \\
\hline 4 & 39 & 1 & $\begin{array}{l}\text { Enavid } 10 \mathrm{mg} . \\
\text { Norethisterone acetate } 5 \mathrm{mg} . \\
\text { Enavid E } \\
\text { Anovlar } \\
\text { Meg. ac. } 3 \mathrm{mg} .+ \text { mestr. } 0.1 \mathrm{mg} . \\
\text { Lyndiol } \\
\text { Volidan } \\
\text { WY } 37071 \mathrm{mg} .+ \text { E.O. } 0.05 \mathrm{mg} . \\
\text { Ethynodiol diac. } 0.5 \mathrm{mg} .+ \text { mestr. } 0.1 \mathrm{mg} .\end{array}$ & $\left.\begin{array}{r}6 \\
5 \\
12 \\
13 \\
3 \\
23 \\
3 \\
6 \\
2\end{array}\right\} 7$ & 73 \\
\hline 5 & 29 & +1 abortion & $\begin{array}{l}\text { Anovlar } \\
\text { Meg. ac. } 2 \mathrm{mg} .+ \text { mestr. } 0.1 \mathrm{mg} \text {. } \\
\text { Lyndiol } \\
\text { B.D.H. sequential } \\
\text { Ethynodiol diac. } 0.5 \mathrm{mg} .+ \text { mestr. } \\
0.1 \mathrm{mg} \text {. } \\
\text { Searle sequential }\end{array}$ & $\left.\begin{array}{r}28 \\
4 \\
2 \\
9 \\
3 \\
6\end{array}\right\} 5$ & 52 \\
\hline 6 & 35 & 2 & $\begin{array}{l}\text { Norethisterone acetate } 5 \mathrm{mg} \text {. } \\
\text { Anovlar } \\
\text { Meg. ac. } 5 \mathrm{mg} \text {. + mestr. } 0.1 \mathrm{mg} \text {. } \\
\text { WY } 37071 \mathrm{mg} \text { + E.0. } 0.05 \mathrm{mg} \text {. } \\
\text { Lyndiol } 2.5\end{array}$ & $\left.\begin{array}{r}11 \\
41 \\
3 \\
6 \\
3\end{array}\right\}$ & 64 \\
\hline 7 & 33 & 2 & $\begin{array}{l}\text { Anovlar } \\
\text { Meg. ac. } 3 \mathrm{mg} .+ \text { mestr. } 0.1 \mathrm{mg} . \\
\text { Lyndiol } \\
\text { Orthonovin } \\
\text { Ethynodiol diac. } 3 \mathrm{mg} .+ \text { mestr. } \\
\quad 0.1 \mathrm{mg} . \\
\text { Ethynodiol diac. } 2 \mathrm{mg} .+ \text { mestr. } 0.1 \mathrm{mg} .\end{array}$ & $\left.\begin{array}{r}15 \\
4 \\
12 \\
8 \\
9 \\
3\end{array}\right\}$ & 51 \\
\hline 8 & 39 & $\begin{array}{c}7 \\
+1 \\
\text { abortion }\end{array}$ & $\begin{array}{l}\text { Anovlar } \\
\text { Lyndiol } \\
\text { Volidan } \\
W Y 3707 \text { 0.1 mg. + E.O. } 0.05 \mathrm{mg} . \\
\text { Searle sequential }\end{array}$ & $\left.\begin{array}{r}26 \\
10 \\
3 \\
6 \\
3\end{array}\right\}$ & 48 \\
\hline 9 & 33 & 3 & $\begin{array}{l}\text { Enavid E } \\
\text { Enavid } 5 \mathrm{mg} . \\
\text { Anovlar } \\
\text { Meg. ac. } 2 \mathrm{mg} .+ \text { E.O. } 0.05 \mathrm{mg} . \\
\text { Meg. ac. } 5 \mathrm{mg} .+ \text { mestr. } 0.1 \mathrm{mg} \text {. } \\
\text { Lyndiol } 3 \mathrm{mg} .+ \text { mestr. } 0.1 \mathrm{mg} \text {. } \\
\text { Meg. ac. } 3 \mathrm{mg} \text { + E.O. } 0.1 \mathrm{mg} \text {. } \\
\text { Meg. ac. } 3 \mathrm{mg} \text { + } \\
\text { Volidan }\end{array}$ & $\left.\begin{array}{r}8 \\
14 \\
19 \\
4 \\
3 \\
3 \\
2 \\
15 \\
3\end{array}\right\}$ & 61 \\
\hline 10 & 42 & $\begin{array}{c}4 \\
+2 \text { abortions }\end{array}$ & $\begin{array}{l}\text { Ethynodiol diac. } 3 \mathrm{mg} .+ \text { mestr. } 0.1 \mathrm{mg} . \\
\text { Anovlar } \\
\text { Meg. ac. } 2 \mathrm{mg} .+ \text { E.O. } 0.05 \mathrm{mg} . \\
\text { Searle sequential }\end{array}$ & $\left.\begin{array}{r}32 \\
17 \\
3 \\
3\end{array}\right\}$ & 55 \\
\hline 11 & 31 & $+2{ }^{3}$ & $\begin{array}{l}\text { Meg. ac. } 3 \mathrm{mg} .+ \text { E.O. } 0.1 \mathrm{mg} . \\
\text { Lyndiol } \\
\text { Orthonovin } \\
\text { Anovlar } \\
\text { Ethynodiol diac. } 0.5 \mathrm{mg} .+ \text { mestr. } 0.1 \\
\text { mg. }\end{array}$ & $\left.\begin{array}{r}6 \\
15 \\
7 \\
13 \\
2\end{array}\right\}$ & 43 \\
\hline 12 & 36 & 2 & $\begin{array}{l}\text { Meg. ac. } 2 \mathrm{mg} .+ \text { mestr. } 0 \cdot 1 \mathrm{mg} \text {. } \\
\text { Anovlar } \\
\text { Lyndiol } \\
\text { Meg. ac. } 3 \mathrm{mg} .+ \text { E.O. } 0 \cdot 1 \mathrm{mg} \text {. } \\
\text { Orthonovin } \\
\text { B.D.H. sequential } \\
\text { Ethynodiol diac. } 3 \mathrm{mg} .+ \text { mestr. } 0 \cdot 1 \\
\text { mg. } \\
\text { Searle sequential }\end{array}$ & $\left.\begin{array}{l}3 \\
9 \\
9 \\
9 \\
3 \\
3 \\
9 \\
7\end{array}\right\}$ & 52 \\
\hline
\end{tabular}

The drug in use at the time the tests were made is printed in italics. E.O. $=$ Ethinyloestradiol. mestr. $=$ Mestranol. diac. $=$ diacetate. meg. ac. $=$ Megestrol acetate. 
less than three years continuously. All except Case 4, who is hypertensive (maximum B.P. 190/110) and is being treated with methyldopa (Aldomet), are believed to be in good general health. The oral contraceptives used include the following: Anovlar; B.D.H. sequential (16 tablets of ethinyloestradiol $0.05 \mathrm{mg}$., followed by five tablets of megestrol acetate $4 \mathrm{mg}$. plus ethinyloestradiol $0.05 \mathrm{mg}$., followed by seven tablets of lactose) ; Enavid $10 \mathrm{mg}$. (norethynodrel $9.85 \mathrm{mg}$. and mestranol $0.15 \mathrm{mg}$.) ; Enavid $5 \mathrm{mg}$. (norethynodrel $5 \mathrm{mg}$. and mestranol $0.075 \mathrm{mg}$.) ; Enavid E (norethynodrel $2.5 \mathrm{mg}$. and mestranol $0.1 \mathrm{mg}$.) ; ethynodiol diacetate $0.5 \mathrm{mg}$., $2 \mathrm{mg}$., and $3 \mathrm{mg}$., each with mestranol $0.1 \mathrm{mg}$.; Lyndiol; Lyndiol 2.5 ; megestrol acetate $2 \mathrm{mg}$. and ethinyloestradiol $0.05 \mathrm{mg}$. or mestranol $0.1 \mathrm{mg}$., $3 \mathrm{mg}$. and mestranol $0.1 \mathrm{mg}$., $4 \mathrm{mg}$. and ethinyloestradiol $0.05 \mathrm{mg}$. (Volidan) and $5 \mathrm{mg}$. with mestranol $0.1 \mathrm{mg}$. ; norethisterone acetate $5 \mathrm{mg}$. ; Orthonovin (norethisterone $2 \mathrm{mg}$. and megestrol $0.1 \mathrm{mg}$.); Searle sequential (10 tablets of mestranol $0.1 \mathrm{mg}$. followed by 10 tablets of mestranol $0.1 \mathrm{mg}$. plus ethynodiol diacetate $0.5 \mathrm{mg}$.) ; and WY 3707 $0.1 \mathrm{mg}$. and $1 \mathrm{mg}$. both with ethinyloestradiol $0.05 \mathrm{mg}$. Details of the tablets used by each patient and the number of cycles on each preparation are shown in Table I, together with the patients' ages and parities.

The liver-function tests have included cephalin cholesterol, colloidal red, and thymol turbidity (empirical tests), plasma bilirubin, plasma glutamic oxalo-acetic transaminase (P.G.O.T.), bromsulphthalein retention (not done in patients with a history of allergy), and plasma alkaline phosphatase. They have been carried out, through the kindness of Dr. F. V. Flynn, in the clinical Biochemistry Laboratory of University College Hospital, the laboratory staff being unaware of the details of treatment.

\section{Results}

Detailed results for each patient are shown in Table II. The highest values for plasma bilirubin encountered were $1.7 \mathrm{mg} . / 100 \mathrm{ml}$. (one case ; next highest, $0.8 \mathrm{mg} . / 100 \mathrm{ml}$.) (direct negative in all cases), for P.G.O.T. 38 Karmen units, for bromsulphthalein retention $6 \%$, and for plasma alkaline phosphatase 10.2 King-Armstrong units. The upper limits of normal for our laboratory are: plasma bilirubin, $0.8 \mathrm{mg}$./ $100 \mathrm{ml}$.; P.G.O.T., $40 \mathrm{Karmen}$ units $/ \mathrm{min} . / \mathrm{ml}$.; bromsulphthalein retention $7 \%$; plasma alkaline phosphatase, 13 King-
Armstrong units $/ 100 \mathrm{ml}$., so that all these results were normal except for the serum bilirubin in one case.

The empirical liver-function tests, on the other hand, have given a number of abnormal results; the cephalin cholesterol was positive in 1 out of 13 tests, the colloidal red was weakly positive in 2 and moderately positive in 4 out of 13 teststhat is, in nearly $50 \%$-while the thymol turbidity was above the normal upper limit of 4 units in three tests and showed flocculation at 4 units in a fourth.

\section{Discussion}

We have encountered none of the pathologically high values for transaminase, bromsulphthalein retention, bilirubin, or alkaline phosphatase reported by Eisalo et al. and by Palva and Mastala, with the exception of one bilirubin result of $1.7 \mathrm{mg} . /$ $100 \mathrm{ml}$. and one doubtfully high P.G.O.T. of 38 Karmen units (the other parameters in both patients being normal). ()ur findings, on the other hand, are in accord with those described by Linthorst and with the experience of Swaab (1964) and of Rice-Wray (1964). Although our series is small, it may be stressed that our patients have all been long-term oral contraceptive users, the duration having been for three to six years without interruption.

In an attempt to explain the discrepancy in the findings of the different groups of workers, attention may first be drawn to the fact that the patients of Eisalo et al. were post-menopausal women whose ages ranged from 52 to 80 years, as were those of Palva and Mustala (age range 62 to 80 years), while our patients (like those of Linthorst, of Swaab, and of Rice-Wray) were all younger women who had not reached the menopause. Our oldest patient was 42. Another difference is that the Finnish workers carried out their tests in the first cycle of treatment, whereas ours were made after many cycles of treatment. It is possible that the abnormal values encountered by the former represent alterations in hepatic function which do not in fact reflect liver damage and which revert to normal as the liver becomes adjusted to the altered hormonal milieu. This point clearly requires further investigation, but it is beyond doubt that during pregnancy, with steadily increasing turnovers of oestrogens and progesterone, the liver adjusts to the increasing demands for conjugation of sex steroid metabolites, so that by the third trimester it is conjugating and inactivating perhaps a

TABLE II.-Results of Liver-function Tests

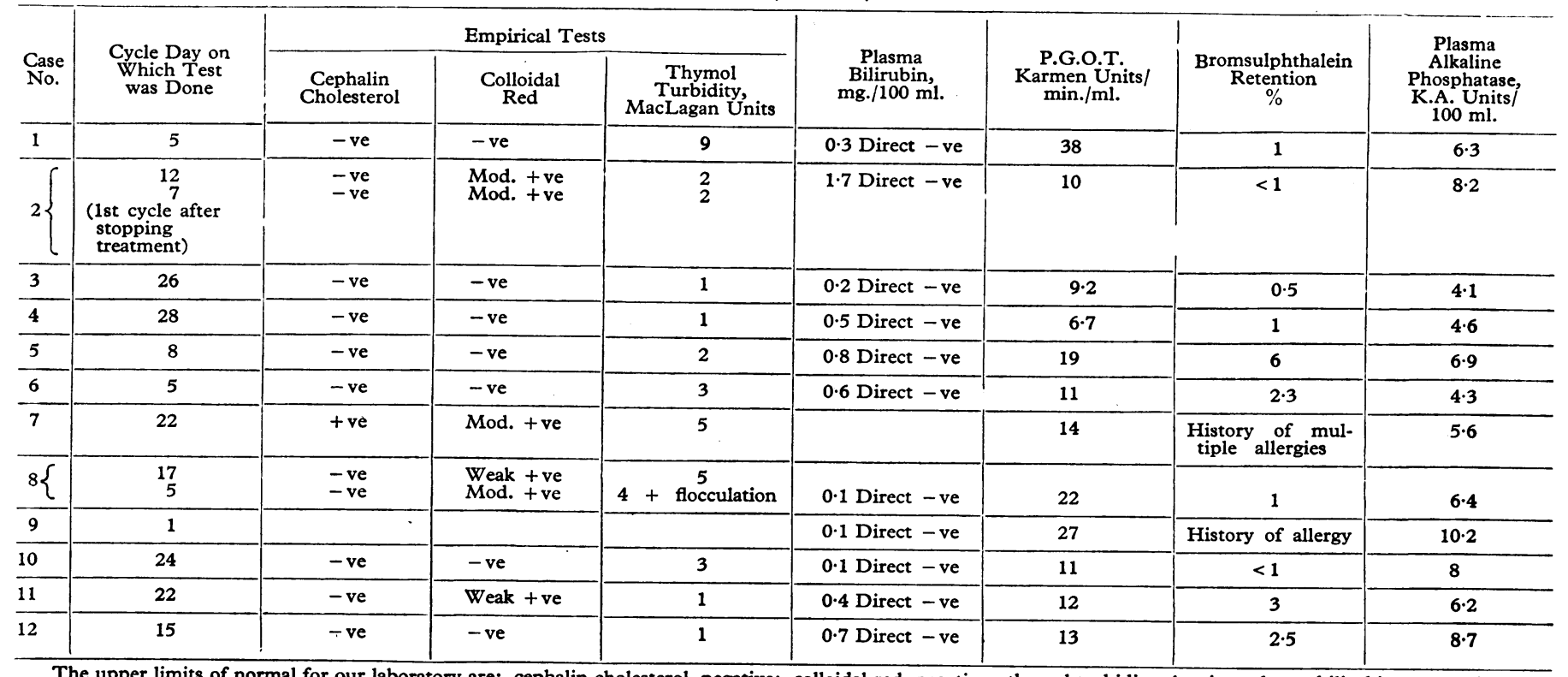
The upper limits of normal for our laboratory are: cephalin cholesterol, negative; colloidal red, negative; thymol turbidity, 4 units; plasma bilirubin, $0.8 \mathrm{mg} . / 100$ ml.,
direct negative; P.G.O.T., 40 Karmen units/min./ml.; Bromsulphthalein retention, $7 \%$; Plasma alkaline phosphatase, $13 \mathrm{King}-\mathrm{Armstrong}$ units/100 ml. 
thousand times more oestrogen than during the menstrual cycle. By the same token it may very well be that the livers of postmenopausal women are less well adapted to oestrogen inactivation than are those of women during the reproductive years; the evidence of altered liver function in post-menopausal women given oral contraceptives might for this reason be still less indicative of toxic change.

Finally, it may not be irrelevant that the majority of evidence suggesting a hepatotoxic effect of oral contraceptives has come from Finland. Such a geographical concentration may be not without significance, suggesting the local prevalence of disturbed hepatic function, a racial difference, or possibly one due to peculiarity of diet.

It is doubtful if any importance need be attached to the abnormal findings in the empirical tests. These tests merely reflect alterations in the plasma proteins, which, of course, are not necessarily the result of liver damage. Since oestrogens are known to increase the thyroid and cortisol-binding globulin of the plasma, for example, it is not surprising that these changes might lead to alterations in the results with the empirical tests. One of our patients (not included among those reported above), who had been treated with a number of different progestogens for many cycles (including Anovlar for 17 cycles) because of severe dysmenorrhœa, was found to have a positive cephalin cholesterol and thymol turbidity of 7 units (colloidal red negative). After stopping treatment for two cycles the results were unchanged, except that the colloidal red was now also positive. Three and a half months later the cephalin cholesterol was still weakly positive, the thymol turbidity was down to 2 units, and the colloidal red was negative. At this time the plasma bilirubin was $0.4 \mathrm{mg} . / 100 \mathrm{ml}$. (direct negative), P.G.O.T. 16 Karmen units, bromsulphthalein retention $2 \%$, and alkaline phosphatase 9.5 King-Armstrong units $/ 100 \mathrm{ml}$. We do not feel that the abnormal empirical test results in this patient were indicative of any liver damage.

\section{Summary}

No pathologically high values for glutamic oxalo-acetic acid transaminase, bromsulphthalein retention, or alkaline phosphatase were encountered in liver-function tests done on 12 women aged 29-42 who have been using oral contraceptives for three to six years continuously. One of these patients had a plasma bilirubin of $1.7 \mathrm{mg} . / 100 \mathrm{ml}$. (normal upper limit 0.8 $\mathrm{mg} . / 100 \mathrm{ml}$.) and one a doubtfully high transaminase of 38
Karmen units, but the other parameters were normal. Some abnormal results in empirical liver-functions tests (cephalin cholesterol, colloidal red, and thymol turbidity) were obtained, but reasons are advanced for doubting whether these are indicative of any hepatotoxic effects.

Our thanks are due to Dr. G. R. Daniel, of John Wyeth and Brother Ltd. ; to Dr. A. David, of British Drug Houses Ltd. ; to Dr. Jürgen Friebel, of Schering, A.G. ; to Dr. N. W. Shephard, of Ortho Pharmaceuticals Ltd. ; to Dr. W. J. Tindall, of Organon Laboratories Ltd. ; and Dr. G. R. Venning, of G. D. Searle \& Co. Ltd., for the generous supplies of oral contraceptives used by the patients mentioned in this report.

AdDENDUM.-Since submitting this paper a number of additional relevant reports have appeared. Bakke (1965) could find no evidence of hepatic impairment in 36 menopausal women, aged 42-77 years, taking mestranol $0.075 \mathrm{mg}$. daily, either alone or in combination with norethynodrel $5 \mathrm{mg}$. The duration of treatment at the time of testing was 1 to 24 months (mean 8.76 months). This work, reported from Seattle, is thus completely at variance with the Finnish findings. However, from Uppsala, Sweden, Cullberg et al. (1965) describe a case of jaundice which developed within a month of taking Lyndiol for about 14 days. Liver biopsy showed intrahepatic cholestasis and hepatocellular damage. These authors suspect that the oral contraceptive was responsible for the development of the jaundice but state : "It should be remembered ... that in the present case and in the solitary cases [mentioned in their paper] the relation between jaundice and drug is not unquestionable." Stoll et al. (1965), in Melbourne, treated four post-menopausal patients with cancer of the breast with six tablets of Lyndiol daily-that is, six times the normal dose-and in all cases found raised S.G.O.T. and serum isocitric dehydrogenase levels. Clinical jaundice was seen in two patients with serum bilirubin levels of up to $41 \mathrm{mg}$./ $100 \mathrm{ml}$. Liver biopsy in all four patients showed centrilobar parenchyma cell necrosis and, in the two with jaundice, cholestasis in the hepatic cells and biliary canaliculi.

\section{REFERENCES}

Adlercreutz, H., and Ikonen, E. (1964). Brit. med. F., 2, 1133.

Bakke, J. L. (1965). Ibid., 1. 631.

Cullberg, G., Lundström, R., and Stenram, U. (1965). Ibid., 1, 695.

Eisalo, A., Järvinen, P. A., and Luukkainen, T. (1964). Ibid., 2, 426.

Eisalo, A., Jarvinen, P. A., and Luuk

Palva, I. P., and Mustala, O.. Ó. (1964). Ibid., 2, 688.

Rice-Wray, E. (1964). Ibid., 2, 1011.

Sotaniemi, E., Kreus, K. E., and Scheinin, T. M. (1964). Ibid., 2, 1264. Stoll, B. A., Andrews, J. T., Motteram, R., and Upfill, J. (1965). Ibid., 1, 723.

Swaab, L. I. (1964). Ibid., 2, 755

Tyler, E. T. (1964a). Ibid., 2, 843.

(1964b). Ibid., 2, 1264 .

\title{
Oral Contraception and Liver-function Tests
}

\author{
ULF LARSSON-COHN,* M.D.
}

Brit. med. F., 1965, 1, 1414-1415

Certain C $17 \alpha$-alkyl substituted testosterones, in particular methyltestosterone (Foss and Simpson, 1959 ; Petersen, 1963), norethandrolone (Nilevar) (Gordon et al., 1962; Shaw and Gold, 1960), and methandienone (Dianabol) (Kaupp and Preston, 1962 ; Wilder, 1962 ; Petersen, 1963), have been shown to be capable of affecting the excretory function of the liver. In a more recent study (Mueller and Kappas, 1964) high doses of natural oestrogens were found to increase bromsulphthalein retention in 28 out of 31 patients.

- Gynaecological Department, Akademiska Sjukhuset, Uppsala, Sweden.
Most oral contraceptive preparations contain a small amount of oestrogen combined with a C $17 \alpha$-alkyl substituted progestogenic steroid. In spite of this, there have been few reports of liver damage or abnormal liver-function tests. In two reports from Finland (Eisalo et al., 1964 ; Palva and Mustla, 1964) a small group of post-menopausal women given Anovlar (norethisterone acetate $4 \mathrm{mg}$. and ethinyloestradiol, $0.05 \mathrm{mg}$.) or Lyndiol (ethynyloestrenol $5 \mathrm{mg}$. and ethinyloestradiol-3methylether (mestranol; $\mathrm{EO}^{3} \mathrm{ME}$ ) $0.15 \mathrm{mg}$.), showed a considerable rise in serum transaminase levels. Furthermore, Tyler (1964), in a series of 214 women who were given a combination 